\title{
SANCTIONS AND EMBARGOES AS A CRISIS RESPONSE INSTRUMENT IN THE CONTEXT OF THE UKRAINIAN CRISIS
}

The paper analyzes the importance of sanctions and embargoes as a tool used by organizations of international crisis management to resolve large-scale crisis events in a peaceful way. The attention is paid to one of these crisis events, the Ukrainian crisis. On the basis of value selected parameters, which are the change of exchange rates and inflation growth in particular countries, it reviews their impact on both stakeholders, namely the countries of the European Union and the Russian Federation.

Keywords: Crisis, sanctions, embargoes, inflation, change of exchange rates.

\section{Introduction}

International organizations use the whole spectrum of crisis management instruments to prevent and solve existing crisis events. Deployment of armed forces is the last resort. The focus is on a peaceful resolution of the crisis. Sanctions and embargoes are one part of them. Through economic and political measures, international organizations try to affect and force the target country to change its behavior. The content of actions varies depending on the specific situation, the nature of the crisis event and other important factors.

\section{Theoretical background and importance of sanctions and embargoes}

Sanctions and embargoes are political and trade restrictions, they are imposed on target countries to maintain or restore peace and security in the region. According to Filip, sanctions are economic instruments used in international crisis management. They keep on influencing the state of a crisis development through the prosperity of another country [1]. They are divided into economic rewards and economic sanctions, the sanctions are a particular form of economic punishment against the target country.

Sanctions and embargoes are put in place by international organizations, namely the United Nations (hereinafter "UN"), the Organization for Security and Cooperation in Europe (hereinafter "OSCE"), but also the European Union (hereinafter "EU"). The main aim is to maintain or restore peace in the affected area. The basis for the use of these instruments is Chapter VII. Article 41 of the UN Charter, which stated: "The Security Council may decide what measures not involving the use of armed force are to be employed to give effect to its decisions, and it may call upon the Members of the UN to apply such measures. These may include complete or partial interruption of economic relations and of rail, sea, air, postal, telegraphic, radio, and other means of communication, and the severance of diplomatic relations" [2].

The EU uses sanctions and embargoes as a tool of the Common Foreign and Security Policy. Through economic and diplomatic sanctions the EU tries to influence the policy of countries, where international law, human rights and freedoms or democratic principles are violated. Their application is in accordance with Article 215 of the EU Treaty [3]. Specific sanctions are applied after approval by the UN Security Council in accordance with the accepted resolution. If necessary, however, the EU can also decide to apply further restrictions. It must always choose the kind which will effectively deal with the situation from a range of possible measures. Types of sanctions are shown in Fig. 1.

Sanctions and embargoes are imposed to stabilize and improve situation in affected area by changing the behavior of main leaders of the country, but also high profile individuals or groups. Of course, the main objective depends on particular circumstances e.g. an arms embargo, a ban on the export of certain goods and other restrictive measures are aimed at limiting the inflow of financial resources to terrorist groups or other destabilizing groups. Imposition of sanctions and embargoes

\footnotetext{
* Veronika Orieskova, Jan Havko

Department of Crisis Management, Faculty of Security Engineering, University of Zilina, Slovakia

E-mail: Veronika.Orieskova@fbi.uniza.sk
} 


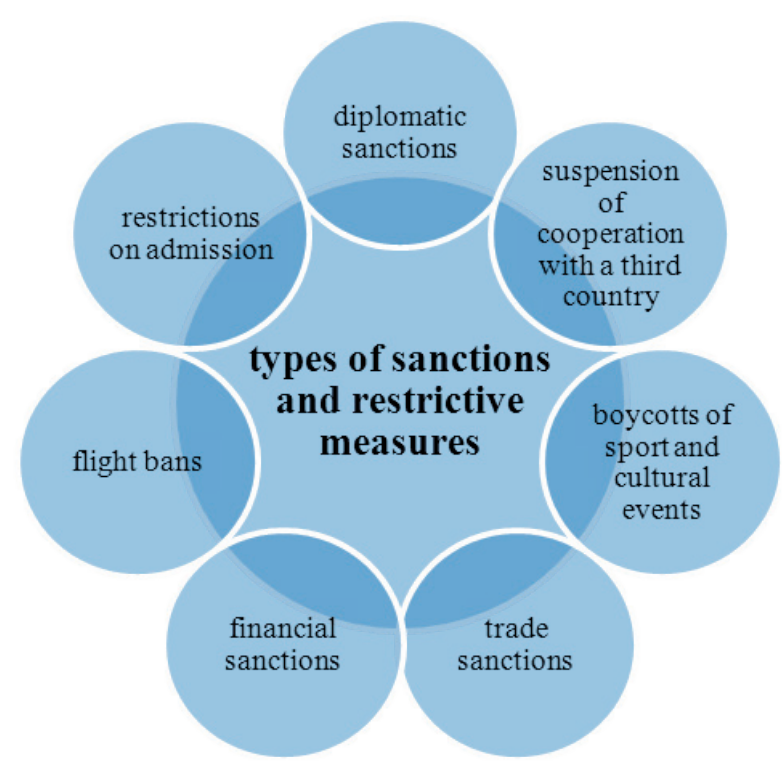

Fig. 1 Types of sanctions and restriction measures imposed by EU [4]

affect mainly the most vulnerable population groups in negative way, so the UN Security Council adopted a more sophisticated approach for planning and imposing sanctions. It is possible to direct them to specific individuals or groups, for example frozen assets, blocked financial accounts and transactions. These sanctions are called smart sanctions [5].

\section{Ukrainian conflict solution through sanctions and embargoes between the EU and Russia}

The conflict between pro-Russian separatists and Ukrainian armed forces threatens peace and security in Europe. It is difficult to clearly identify what launched a chain of events which resulted in the current situation. We can only assume that it is caused by dissatisfaction of Ukrainian people associated with the results of the elections in 2004 or suspension of negotiations about the EU Association Agreement. Organizations of international crisis management take initiative to end the conflict in a peaceful way and as soon as possible. The EU decided to solve the situation in February 2014 by imposing sanctions (for example freezing Ukrainian National Accounts), then the sanctions were imposed direct towards the Russian Federation, which supports, according to the media information, activities of pro-Russian separatists.

Mentioned sanctions imposed against the Russian Federation include:

- an asset freeze for certain individuals (total of 151) and entities (total of 37) and a travel ban for certain individuals because of their direct involvement in the situation development in Ukraine [6];
- the sectorial sanctions target Russia's oil industry, financial sector and the military or arms industry, which include following restrictions:

- restrictions on financing some companies owned by the Russian government (banks, oil companies and companies and entities engaged in production, conception, sales or export of military equipment or services); this restriction includes a prohibition to deal in security and money market instruments, issued by the companies mentioned above, with a maturity above 30 days;

- restrictions to provide, directly or indirectly, loans or credit to mentioned companies with a maturity exceeding 30 days;

- restrictions on export of military and dual-use items to Russia and for use in Russia;

- restrictions on the export and supply of certain oil-related goods and technologies to Russia and for use in Russia [7, 8 and 9];

- imposition of the strictest sanctions targeted towards trade with Crimea and Sevastopol in response to the illegal annexation of Crimea and Sevastopol.

General Assembly of the UN adopted resolution no. 68/262 about territorial integrity of Ukraine which recalls the obligations of all states under Article 2 of the Charter of the UN to refrain in their international relations from the threat or use of force against the territorial integrity or political independence of any State, and to settle their international disputes by peaceful means [10]. This resolution notes that the referendum held in the Autonomous Republic of Crimea and the city of Sevastopol in March 2014 was not authorized by Ukraine. In direct connection with the UN resolution, the EU Council adopted decision No. 2014/386/ CFSP and EU Regulations No 692/2014 (June 2014) and No $825 / 2014$ (July 2014), which were significantly extended by the EU Regulation No 1351/2014 in December 2014. Through this regulation any trade and investment in Crimea and Sevastopol was practically restricted.

The Russian Federation responded with sanctions against the EU through adoption of retaliatory measures in March 2014. At first, it was asset freeze and travel ban for people, also even government officials to Russia. In August, the Russian president V. V. Putin signed a decree on the application of specific economic measures, which imposed annual ban on import majority of agricultural products from countries, which had adopted sanctions. Next day, the Russian Federation government adopted a decree with list of countries and different products to which the embargo is targeted. It should be noted that before imposing an embargo, food export from the EU to Russia was approximately about 11.8 billion, which represents $10 \%$ of Russian consumption [11]. 


\section{The consequences of sanctions on changes in exchange rates and inflation growth}

The most apparent consequences of sanctions are in the economic field. It also includes changes of euro and ruble exchange rates in relation to US dollar. Imposition of sanctions also affects the inflation growth in selected countries. We perceive it as a direct consequence of adopting the restriction measures. Changes of several commodities prices, for example crude oil and gas, can be considered as an indirect consequence. Sanctions against Russia were adopted in March and December. Restriction measures adopted in December can be classified as more strict.
In August, Russia responded by imposing an embargo on import of agricultural products from countries which had adopted restrictive measures against it. This paper pays attention mainly to the development of mentioned indicators, namely in short term after imposition of sanctions.

Progress of exchange rate reflects the confidence level of financial markets to a specific country. Figure 2 shows change of euro and ruble exchange rates against exchange rate of US dollar. Although euro is relatively stable, it has depreciated gradually since September 2014. That decrease can be caused by solving the Greek debt issue. It is influenced by embargo introduced in August 2014 only partially. On the other hand, ruble exchange

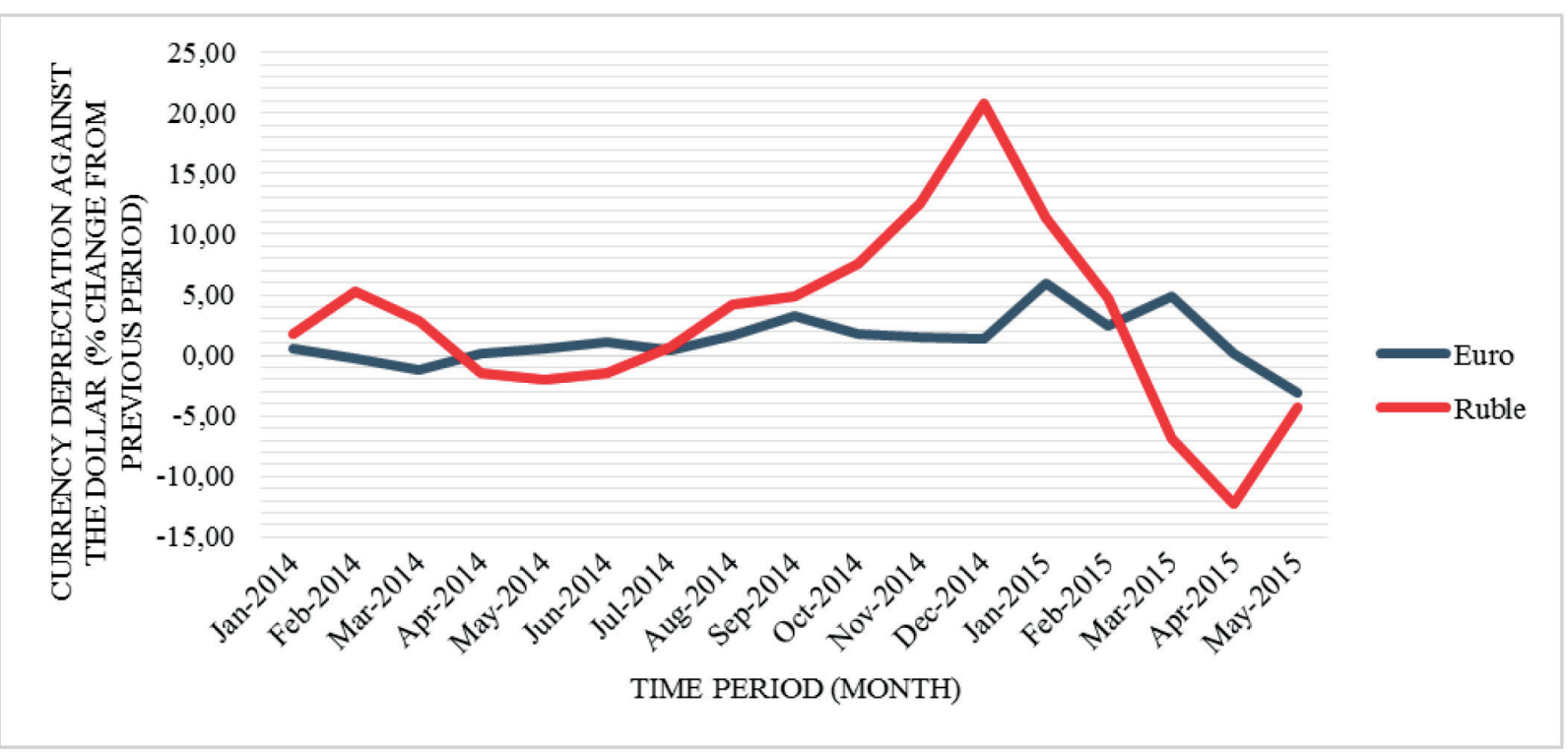

Fig. 2 Graph of the euro and ruble exchange rate development [12]

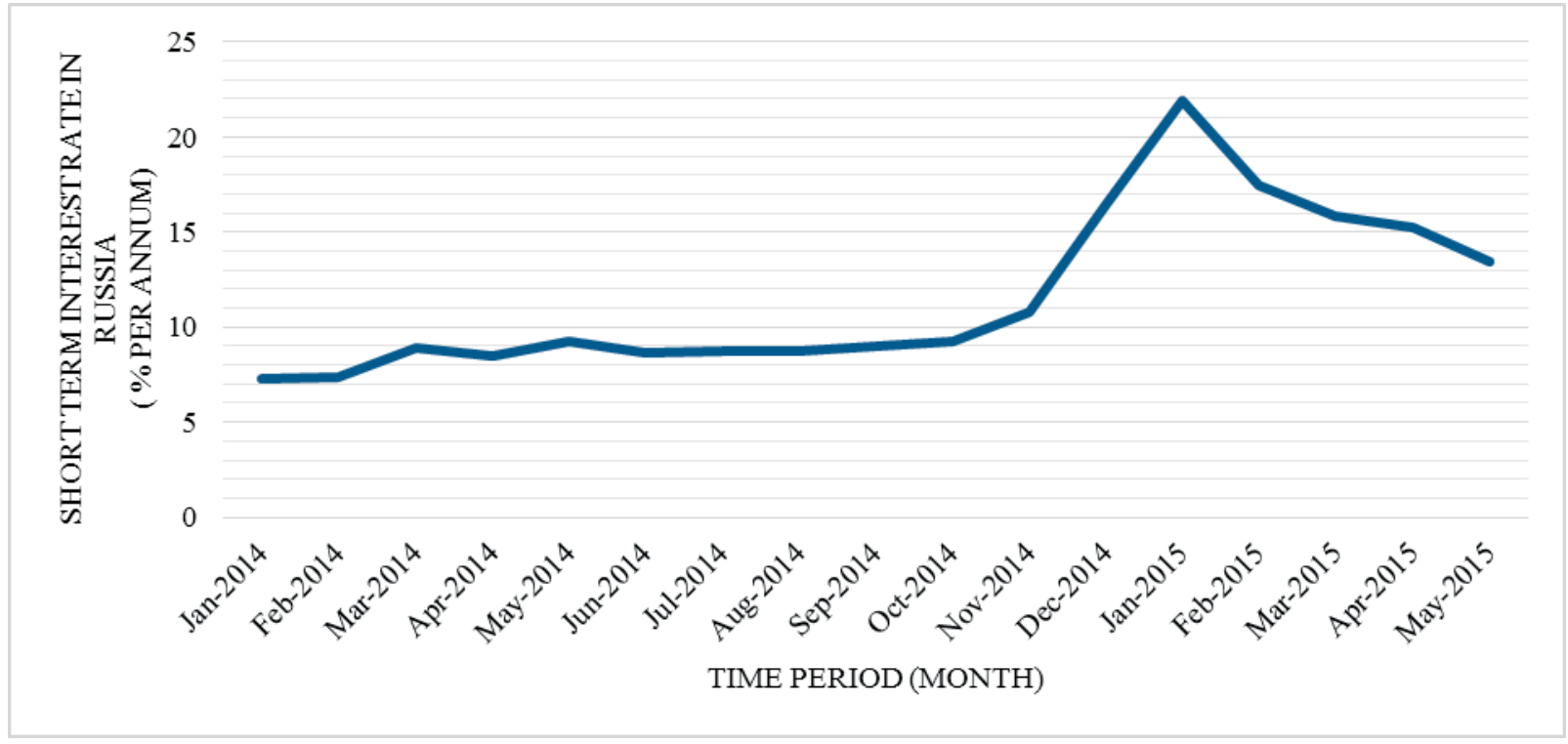

Fig. 3 Graph of the short term interest rate in Russian Federation [13] 
rate is significantly influenced by EU sanctions. Due to the first sanctions introduced in March 2014, its exchange rate decreased. However, the decrease was not so significant, so the ruble remained relatively stable. After stricter sanctions imposed in December 2014, exchange rate of the ruble had already declined significantly, namely by over $10 \%$ per month. Russia has responded by adopting several monetary measures. Through them, the ruble exchange rate slightly appreciated in March 2015. It can be assumed that development of the ruble exchange rate will be influenced by Council Decision 2015/959 CFSP, which extended the sanctions until 23 June 2016.

The short-term interest rate was and still is one of the most important tools used to stabilize ruble exchange rate. Its development is shown in Fig. 3. After imposition of the sanctions in December 2014, the short-term interest rate in Russia increased above $20 \%$. The main aim of this measure was to avoid mass cash withdrawal and thus subsequent loss of Russian banks liquidity. Currently, value of the short-term interest rate is still higher than it was before sanctions imposing. Totally it was more than $7 \%$. The EU short-term interest rate did not exceed $0.3 \%$ during selected months [13].

The average value of long-term interest rate was $8 \%$ in the Russian Federation, but after imposition of the sanctions in December 2014 it increased to $10 \%$. On the contrary, value of the long-term interest rate in the $\mathrm{EU}$ has been decreasing since January 2014. It decreased from $3.21 \%$ in January 2014 to $0.85 \%$ in April 2015 [13].

Inflation, as an indicator, expresses the increase of the price level. The embargo imposed in August 2014 connected with the import of agricultural products should cause, according to the economic theory, an increase of inflation in Russia and deflation in the EU. Figure 4 shows progress of inflation in the OECD (only
Europe countries) and Russian Federation. Fig. 4 shows a slight progress of inflation in Russia after August 2014 due to the lack of goods, which were related to the embargo.

The highest inflation rate in Russia, since the sanctions imposition, was during December 2014 and January 2015. It was directly caused by the depreciation of ruble exchange rate and increase of the short-term and long-term interest rates. Although, inflation rate in Russia is still growing after February 2015, its growth is slower. An inflation development in OECD - Europe countries shows that the embargo imposed against European countries did not have such substantial impact [14].

Based on the selected indicators, we can conclude that the EU sanctions significantly influence economy of the Russian Federation. The European Commission estimates that gross domestic product (hereinafter "GDP") growth in Russia will decrease at least by $1.1 \%$ in 2015 and it will be influenced by sanctions against Russia. Furthermore, ruble exchange rate decreased and significant outflow of capital from Russia began. Overall, capital value is in the amount of 130 billion dollars. According to estimates of the European Commission, the sanctions will also reduce GDP growth in the EU by 0.2-0.3\% in 2015. According to available information sources, decrease of export from the EU to Russian federation is in the amount of more than $60 \%$ [15].

In addition to the changes in exchange rates and inflation rate caused directly by sanctions and embargoes, there are also other indicators which should be paid attention to. It can be, for example, price of strategic raw materials, where is inherently oil and natural gas. These commodities are among the most important sources of the Russian Federation income. The EU together with the United States has the political and economic instruments to reduce prices of these commodities, either by

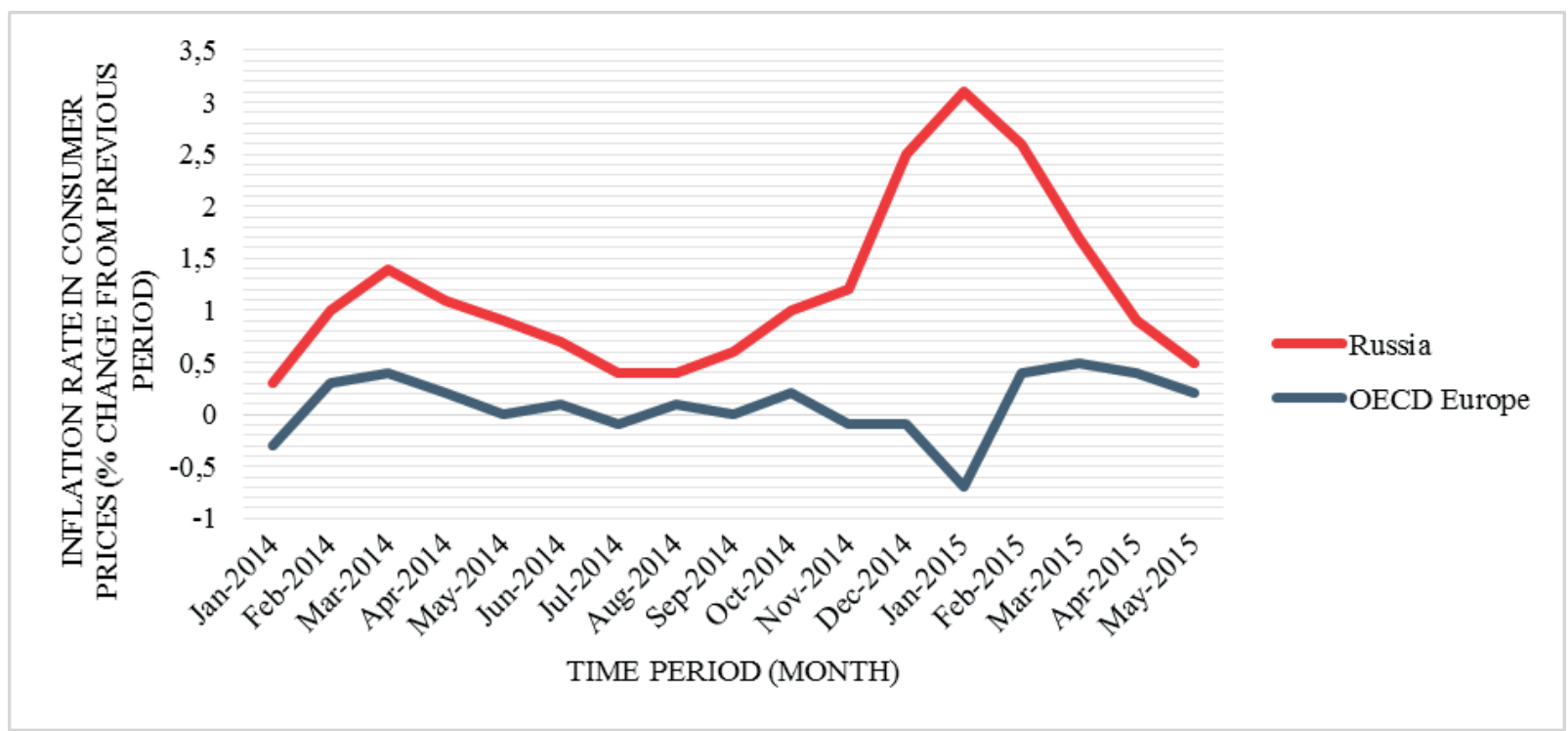

Fig. 4 Graph of the inflation rate development [14] 


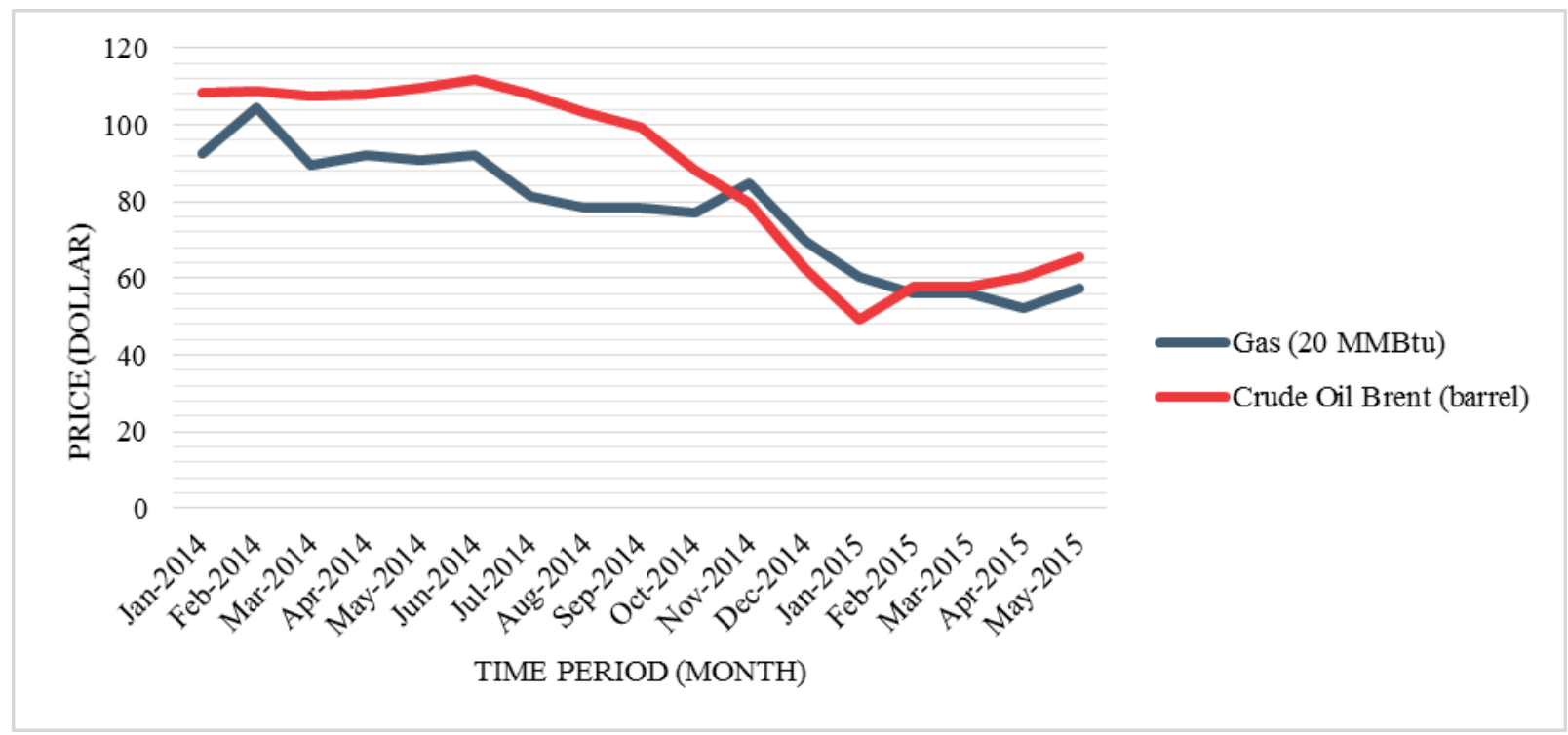

Fig. 5 Graph of the gas and oil stock market price development [16 and 17]

influencing the world stock exchanges, or pressure on OPEC members (OPEC means Organization of the Petroleum Exporting Countries). In Fig. 5 we can see a decline in oil prices, which is more than $50 \%$ in one year [16]. However, we can only assume that oil prices decline was an indirect revenge of the United States and other countries to which Russia imposed embargo on goods import. The price of gas did not fall as much as the oil price (Fig. 5). The gas price declined more than $25 \%$ in one year [17]. More significant decline was after imposing sanctions against Russia in December 2014.

Situation in Ukraine influences the global security environment. Changes in the security environment also reflect on the economic environment, for example by growth of strategic commodities prices, namely oil and gas. Mentioned strategic commodities are necessary for the sustainable economy of each country. Especially ensuring resources for future development of the country is considered as a strategic priority of security [18]. Sanctions raised concerns about the possible suspension of raw materials supply to Europe. Especially Eastern Europe countries are dependent on Russian gas. These countries rely on Russia for at least $60 \%$ of their gas [19]. Commodity prices did not increase, on the contrary, price decreased. Based on the current prices development, it can be stated that they will be regulated in some way by countries, which adopted sanctions against Russia. It could be meant, from one point of view, as another form of sanctions against Russia. However, this statement is not possible to substantiate by any official sources.

\section{Conclusion}

We can make some conclusions based on the description of sanctions and embargoes as such, but these conclusions are mainly based on characterization of specific measures imposed by the EU against the Russian Federation. Imposition of sanctions by the EU definitely disrupted economy of the Russian Federation. The exchange rate of ruble decreased and inflation rate in the country increased. Whether the adoption of specific restrictive measures fulfilled the primary purpose is already difficult to say with certainty. The main purpose of all these measures was the peaceful resolution of the conflict in Ukraine. Another purpose was to achieve that Russia ceased to support efforts of Crimea inhabitants to affiliate to the Russian Federation by its activities. Despite of the ceasefire, there are still a lot of attacks and fights, so the effectiveness of measures is questionable.

The consequence of sanctions imposed by the Russian Federation to the EU in the context of criteria selected by us does not seem so significant. However, we paid attention only to development of euro and ruble exchange rates, inflation growth and changes of oil and natural gas prices, this finding is not absolute. It is also necessary to take into consideration other factors to comprehensively assess the impact of the adopted measures. Because of the limited scope of the paper, it is not possible. 


\section{References}

[1] NOVAK, L. et al.: Resource Planning for Solution of Crisis Situations (in Slovak), Bratislava: Vysoka skola ekonomie a manazmentu verejnej spravy, 2010.

[2] Charter of the United Nations. [on-line cit.: March, 04, 2015]. Available at: http://www.mzv.sk/servlet/newyorkosn?MT=/App/ WCM/ZU/NewYorkOSN/main.nsf/vw_ByID/ID_621F5291AE4A5FD4C125715B004FFE51_SK\&TG=BlankMaster\&URL=/ App/WCM/ZU/NewYorkOSN/main.nsf/vw_ByID/ID_14A4A60B573D8E62C12570DD0048A478_ $\mathrm{SK} \&$ OpenDocument $=\mathrm{Y} \& \mathrm{LANG}=\mathrm{SK} \& \mathrm{HM}=25-\mathrm{Charta} \& \mathrm{OB}=0$.

[3] Treaty on European Union. Treaty on the Functioning of the European Union. Consolidated texts in terms of the Lisbon Treaty. Ministerstvo zahraničných vecí Slovenskej republiky: AVI TOBA PRESS, s.r.o., 2008.

[4] European Commission - Restrictive measures. [on-line cit.: March, 08, 2015]. Available at: http://eeas.europa.eu/cfsp/sanctions/ docs/index_en.pdf.

[5] Security Council Sanctions Committees: An Overview. [on-line cit.: March, 08, 2015]. Available at: http://www.un.org/sc/committees/ index.shtml.

[6] Council Regulation (EU) No 269/2014 concerning restrictive measures in respect of actions undermining or threatening the territorial integrity, sovereignty and independence of Ukraine. [on-line cit.: March, 16, 2015]. Available at: http://eur-lex.europa.eu/legalcontent/SK/TXT/HTML/?uri=CELEX:32014R0269\&from=SK.

[7] Council Decision 2014/512/CFSP concerning restrictive measures in view of Russia's actions destabilising the situation in Ukraine. [on-line cit.: March, 16, 2015]. Available at: http://eur-lex.europa.eu/legal-content/SK/TXT/HTML/?uri=CELEX:32014D0512 $\&$ from=EN.

[8] Council Regulation (EU) No 833/2014 concerning restrictive measures in view of Russias actions destabilising the situation in Ukraine. [on-line cit.: March, 16, 2015]. Available at: http://eur- lex.europa.eu/legal-content/SK/TXT/HTML/?uri=CELEX:32014 R0833\&from=EN.

[9] Council Regulation (EU) No 960/2014 amending Regulation (EU) No 833/2014 concerning restrictive measures in view of Russia's actions destabilising the situation in Ukraine. [on-line cit.: March, 16, 2015]. Available at: http://eur-lex.europa.eu/legal-content/SK/ TXT/HTML/?uri=CELEX:32014R0960\&from=EN.

[10] Resolution Adopted by General Assembly No. 68/262 Territorial integrity of Ukraine. [on-line cit.: March, 16, 2015]. Available at: http://www.un.org/en/ga/search/view_doc.asp?symbol=A/RES/68/262.

[11] Russia Hits West with Food Import Ban in Sanctions Row. [on-line cit.: March, 16, 2015]. Available at: http://www.bbc.com/news/ world-europe-28687172.

[12] Monthly Monetary and Financial Statistics (MEI): Exchange Rates (USD Monthly Averages). [on-line cit.: July, 16, 2015]. Available at: http://stats.oecd.org/index.aspx?queryid=169.

[13] Monthly Monetary and Financial Statistics (MEI): Interest Rates. [on-line cit.: July, 16, 2015]. Available at: http://stats.oecd.org/ index.aspx?queryid=86.

[14] Consumer Prices (MEI): Consumer Prices. [on-line cit.: July, 16, 2015]. Available at: http://stats.oecd.org/Index. aspx?DatasetCode=MEI_PRICES\#.

[15] JANSEN, J.: EU Sanctions Against Russia: New Targets and State of Play. [on-line cit.: March, 16, 2015]. Available at: https://www. dlapiper.com/en/us/insights/publications/2015/02/eu-sanctions-against-russia/.

[16] Brent crude - current and historical price of Brent crude oil (in Czech). [on-line cit.: July, 16, 2015]. Available at: http://www.kurzy. $\mathrm{cz} /$ komodity $/$ index.asp?A=5\&idk=38\&od=18.3.2014\&do=17.3.2015\&curr=USD.

[17] Natural gas - current and historical gas prices (in Czech). [on-line cit.: July, 16, 2015]. Available at: http://www.kurzy.cz/komodity/ index.asp? $\mathrm{A}=5 \& \mathrm{idk}=43 \& \mathrm{od}=18.3 .2013 \& \mathrm{do}=17.3 .2015 \&$ curr $=$ USD.

[18] KELISEK, A. et al.: Economic Security - A Principal Component of Multilevel Security Cconcept in Global Economy. Communications- Scientific Letters of the University of Zilina, 13(2), 2011, pp. 44-48.

[19] SVENTEKOVA, E. et. al.: Solution of Gas Crisis as a Task of Risk Management in Slovakia, Proc. of WMSCI 2009 The 13 th World Multi-Conference on Systemics, Cybernetics and Informatics, Jointly with the 15th Intern. Conference on Information Systems Analysis and Synthesis, ISAS 2009, 2009, pp. 384-388. 